\title{
Public Perception toward the Impact of People Activities in Sand and Stone Mining on Economy and Environment in Nulokla Village Jayapura
}

\author{
Sarlota Ratang \\ University Cenderawasih, Papua, Indonesia \\ ratangsarlota@yahoo.co.id
}

\begin{abstract}
This research is aimed to determine the public perception towards the impact of people activities in sand and stone mining in Nolokla village, Jayapura, determine the people income levels of sand and stone mining in Nolokla village Jayapura, and the impact which is felt by the miners in terms of the surrounding environment. This research is a survey with descriptive analysis method. The positive impact in term of economics, sand and stone mining in Nolokla is increasing the income of the miners. The gross income of sand miners per day is Rp. 1.037.500, while for stone miners is Rp. 1.365.000. However, the negative impact of the activity is environmental degradation, water flow decrease and critical land.
\end{abstract}

Keywords: Perception, miners, sand, stone, income and environment

\section{Introduction}

Mining activities sometimes cause problems. It is not just a matter of the mine, but also the environmental issues. In environmental management based on preservation capability, the relationship between human and the environment is always in optimum condition, human can utilize the resources under control and the environment is able to create a source for cultivating. Environmental management aims to achieve harmonious relationship between human and the environment as the goal of a complete Indonesian development, controlled use of resources wisely, the realization of Indonesian as the trustees of the environment, the implementation of sustainable development for the importance of present and future generations, sheltered State against the impact activities outside the territory which causes damage and environmental pollution (Subagya, 2000; Binns \& Nel, 2003). It requires serious knowledge (steady), both in terms of juridical and technical aspects of mining are required. Indonesian government has issued Law No. 11/1967 about the regulation of Mining Basic Provisions. According to the law, the extractive minerals of group C is not strategic and vital, it is managed by the Local Government by issuing a license of regional mining (Campbell \& Williams, 1999; Costa \& Scoble, 2006).

The regional income of Jayapura in 2009 is about 36.360.278.665 with the target of 23.901.131.398 (152\%) (Dispeda, 2010). The income of 36 billion is derived from a variety of sectors, including the tax of hotel, restaurants, entertainment venues, billboards, street lights and minerals group C. Up until now, material group $\mathrm{C}$ is an idol in giving the largest contribution than other sectors. Jayapura district has some location in excavating materials category C such as East Sentani, West Sentani, Sentani Hawaii, Nimboran, Unurumguai, Kemtuk, and Nimbokrang. Nolokla is one of the villages located in East Sentani. The people consist of local or natives and settlers. Nolokla village potential in terms of natural resources, especially the crops such as sand, stone and gravel called class $\mathrm{C}$ mining materials can be regarded as a source of livelihood for most villagers in Nolokla (Drasch et al., 2001; Foli, 2004). The location of C exists along the edge of one of the rivers, as well as around some of the mountain foot in the village. The characteristics of the people's activities of $\mathrm{C}$ mining, especially sand and rock, and mining techniques are relatively easy with open-pit mining system, the simple equipment, requires no special expertise, simply done by labor-intensive and low costs. The motives for miners are different, anyone doing this job as a main job and some are doing as a side job. The objective of this research is to know the public perception towards the impact of people activities in sand and stone mining in Nolokla village, Jayapura, to analyze the factors that affect the income of sand and stones mining in Nolokla Jayapura and analyze the constraints and opportunities in sand and stones mining activities in Nolokla, Jayapura (Mosley \& Sharp, 2004; Horowitz, 2006).

\section{Methodology}

This research focuses on Nolokla Village, East Sentani District, Jayapura, precisely along the river of Yabawi with a length of 1,500 meters. The total sample is 21 respondents of 210 sands and stones miners in this 
location (Nazir, 2005:279). The data was collected by the primary data, the data obtained from direct observation to the research location and interviews the miners. To calculate how many revenue day of mining sand and stone used analysis tools that the average value quoted Yuwono (Budi-Yuwono, 1996:144). The data was analyzed using descriptive analysis.

\section{Findings and Discussion}

Description of the sand miners is the people who do the activities in indigenous rights land (70\%), land without a ruler (20\%), and the land with work status (10\%). The longest period time is 1-5 years (50\%), 6-10 years (40\%) and $10 \%$ is $10-15$ years. Working hours per day is for $1-5$ hours (50\%) or 5-10 hours per day (50\%), so the average time is about 5-6 hours per day. The sand mining crop was about 1-5 ret per day (85\%) or an average of 4 per day at a price per ret is 250,000 , - Then, the sand miner description is the pople who do the activities in indigenous rights land (65\%), land without a ruler (15\%), and the land with work status $(20 \%)$. The longest period time is $1-5$ years $(50 \%), 6-10$ years $(40 \%)$ and $10 \%$ is $10-15$ years. Working hours per day is for 1-5 hours (50\%) or 5-10 hours per day (50\%), so the average time is about 5-6 hours per day. The stone mining crop is about 1-5 ret per day (75\%) or an average of 4 per day at a price per ret is 300,000 .

Income analysis: In order to fulfill life need, people should have enough income. From the income, they can get the goods and services required. In order to get the income, they have to work. The sand and stones miners get the income from their activities in producing and selling the sands and stones. They have a various income, from 2-10 ret depends on their works. Based on the analysis and interviews to 20 respondents as the sample, the gross income each day is about Rp. 1.037.500,00 with the lowest income, Rp 500.000 (2 rets of sands) and the highest one is $\mathrm{Rp} 2.000 .000$ (8 rets of sands). While the gross income of stones miners each day is $1.365 .000,000$ with the lowest income, Rp 600.00 ( 2 rets of sands) and the highest one Rp 3.000 .000 (10 rets of stones)

Physical condition in Nolokla village, Jayapura: Figure 1 shows an environment physical condition that occurs because of the sand and stones mining along Yabawi River, Nolokla village Jayapura.

Figure 1: Waterflow reduction

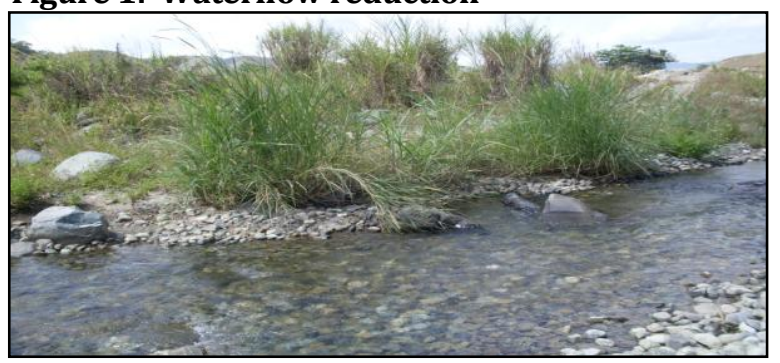

Water is a very important need for human survival. If water is used for drinking, cooking, washing and bathing to be reduced and turbid due to the sand and stones mining were seen in figure 5.1, the survival will automatically be disrupted. Then, the people who live around have to spend money to buy water to meet their daily needs.

Figure 2: Critical Land

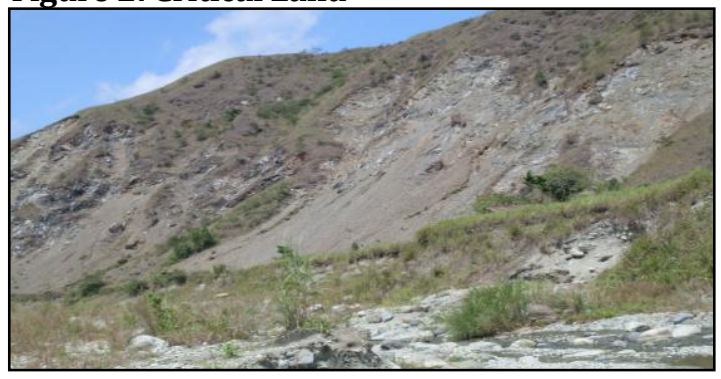


Lahan Kritis: Figure 2 shows the occurrence of critical land. The areas before mining activities commonly planted various plants, vegetables, plant cover and the protective ground, because of the activity, it became degraded land. As a result, the people have to buy vegetables for their daily needs. Also the green land becomes barren. Moreover, it can cause air pollution as a result of degraded land that is not good for the health. Because the dust sucked inside the body in long period can lead to quite dangerous disease.

\section{Figure 3: Land damage}

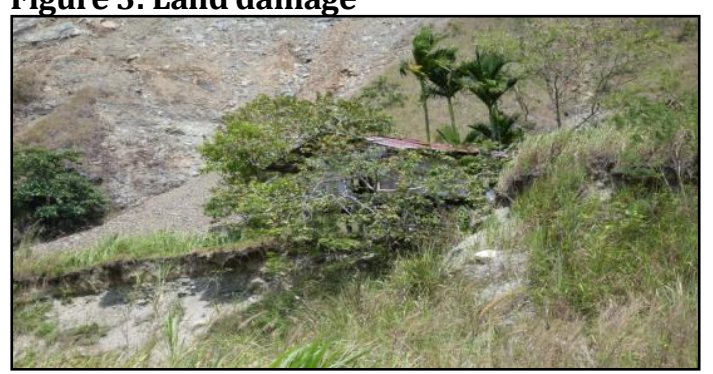

Degradasi lingkungan: Damage that occurs at this time is quite alarming, it can be seen in the image above. This is as a result of the use of land as sand and stones land excavation that do not pay attention to the techniques of conservation of soil and water, which causes soil erosion process that exceeds the rate of formation of the soil (erosion exceeding the limit). If the erosion process is allowed prolonged, there will be floods and landslides. This damage also affects the balance and damages the ecosystems in order watersheds as well as the disruption people life.

The impact of mining activities towards social relationship, lifestyle, and social change

\begin{tabular}{|c|c|c|c|c|c|c|c|}
\hline \multirow{2}{*}{$\begin{array}{l}\text { The period } \\
\text { the activity }\end{array}$} & \multicolumn{2}{|c|}{$\begin{array}{c}\text { Social } \\
\text { ofrelationship }\end{array}$} & \multicolumn{2}{|l|}{ lifestyle, } & \multicolumn{2}{|c|}{ social change } & \multirow[b]{2}{*}{ Not exist } \\
\hline & Not exist & exist & $\begin{array}{l}\text { exist } \\
\text { (Ada) }\end{array}$ & Not exist & Enmity & Jelousy & \\
\hline 3 & 2 & 1 & 1 & 2 & & 1 & 2 \\
\hline 4 & 1 & & 1 & & & 1 & \\
\hline 5 & 2 & 4 & 4 & 2 & 1 & 4 & 1 \\
\hline 7 & 1 & & & 1 & & & 1 \\
\hline 8 & 1 & & & 1 & & & 1 \\
\hline 10 & 5 & 1 & 1 & 5 & 1 & & 5 \\
\hline 15 & 1 & 1 & 1 & 1 & & 1 & 1 \\
\hline
\end{tabular}

The research results for the impact of sand stone mining towards social relationships is $65 \%$ no impact, $25 \%$ small effect, jealousy or lack of harmony among the miners. Lifestyle, and social changes have no impact. While the impact of mining on the environment is $80 \%$ erosion, especially on a rainy day that $25 \%$ occurred during 2 days and consequently also pollute water. Impact on the house, the garden, the main work and additional work does not give a great impact. The impact of mining on the health is $35 \%$ moderate pain and $35 \%$ severe pain. The miners with terminally ill, $27 \%$ of people who were vomiting blood due to the work hard. Place of treatment is an alternative treatment (45\%) or taking the medication leaves from nature (Drug village) by $55 \%$.

Kesimpulan: After the analysis done, the positive impact of sand and stones mining operations in Nolokla jayapura is in economic terms because it can increase the income of the miners of sand and stone. It can be seen from the average gross daily income of sand miners is about Rp. 1.037.500,00 with the lowest income, Rp 500.000 ( 2 rets of sands) and the highest one is $\mathrm{Rp} 2.000 .000$ ( 8 rets of sands). While the gross income of stones miners each day is $1.365 .000,000$ with the lowest income, $\mathrm{Rp} 600.00$ (2 rets of sands) and the highest one Rp 3.000.000 (10 rets of stones). In terms of the environment, sand and stone mining around the village 
gives negative impact because of the occurrence of environmental degradation, reduction in water flow and the critical lands.

Saran: The impact of sand and stone mining has positive impact in economic because it can increase the income of the miners while in terms of environmental impact, it gives negative ones. It requires serious attention from the miners in doing the activities, so that the environment is maintained from erosion, water flow. The need of keeping the health is also important so they can stay doing healthy in their activities.

\section{References}

Binns, T. \& Nel, E. (2003). The village in a game park: Local response to the demise of coal mining in KwaZuluNatal, South Africa. Economic Geography, 79(1), 41-66.

Budi-Yuwono, N. (1996). Pengantar Statistic Economic dan Perusahaan, Jilid II, UPP AMP YKPN, Yogjakarta.

Campbell, C. \& Williams, B. (1999). Beyond the biomedical and behavioral: towards an integrated approach to HIV prevention in the southern African mining industry. Social Science and Medicine, 48(11), 162539.

Costa, S. \& Scoble, M. (2006). An interdisciplinary approach to integrating sustainability into mining engineering education and research. Journal of Cleaner Production, 14, 366-373.

Dinas Pendapatan Daerah Kabupaten Jayapura, 2010.

Drasch, G., Bose-O'Reilly, S., Beinhoff, C., Roider, G. \& Maydl, S. (2001). The Mt. Diwata study on the Philippines 1999-- assessing mercury intoxication of the population by small scale gold mining. Science of Total Environment, 267(1-3), 151-68.

Foli, G. (2004). Physio-Chemical Evaluation of Some Mining Impacted Water Bodies within the Obuasi Environment, Department of Geology, University of Ghana, Legon.

Horowitz, L. (2006). Mining and sustainable development. Journal of Cleaner Production, 14(3-4), 307-308.

Nazir, M. (2005). Metode Peneltian cetakan keenam, penerbit ghalia Indonesia.

Mosley, L. M. \& Sharp, D. S. (2004). The hydrogen sulfide (H2S) paper-strip test: A simple test for monitoring drinking water quality in the Pacific Islands (No. 373).

Suva, Fiji: South Pacific Applied Geoscience Commission (SOPAC).

Subagya, P. (2000). Dasar-dasar operations research, BPFE, Jogjakarta. 